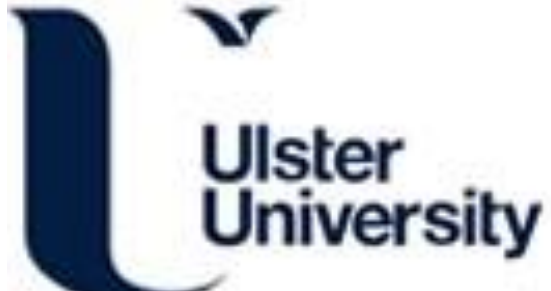

\section{Assessment of candidate folate sensitive-differentially methylated regions in a randomised controlled trial of continued folic acid supplementation during the second and third trimesters of pregnancy}

Harrison, A., Pentieva, K., Ozaki, M., McNulty, H., \& Parle-McDermott, A. (2019). Assessment of candidate folate sensitive-differentially methylated regions in a randomised controlled trial of continued folic acid supplementation during the second and third trimesters of pregnancy. Annals of Human Genetics, 83(1), 23-33. https://doi.org/10.1111/ahg.12281

Link to publication record in Ulster University Research Portal

Published in:

Annals of Human Genetics

Publication Status:

Published (in print/issue): 01/01/2019

DOI:

10.1111/ahg. 12281

Document Version

Author Accepted version

\section{General rights}

Copyright for the publications made accessible via Ulster University's Research Portal is retained by the author(s) and / or other copyright owners and it is a condition of accessing these publications that users recognise and abide by the legal requirements associated with these rights.

\section{Take down policy}

The Research Portal is Ulster University's institutional repository that provides access to Ulster's research outputs. Every effort has been made to ensure that content in the Research Portal does not infringe any person's rights, or applicable UK laws. If you discover content in the Research Portal that you believe breaches copyright or violates any law, please contact pure-support@ulster.ac.uk. 
Research Article

Assessment of candidate Folate Sensitive-Differentially Methylated Regions in a randomized controlled trial of continued folic acid supplementation during the second and third trimesters of pregnancy.

Running title: Folic Acid intervention in pregnancy and DNA methylation changes

ALAN HARRISON ${ }^{1}$, KRISTINA PENTIEVA ${ }^{2}$, MARI OZAKI ${ }^{1}$, HELENE $^{2}$ MCNULTY, ${ }^{2}$ AND ANNE PARLE-MCDERMOTT ${ }^{1 *}$.

${ }^{1}$ School of Biotechnology, Dublin City University, Dublin 9, Ireland.

${ }^{2}$ Northern Ireland Centre for Food \& Health, Biomedical Sciences Research Institute, Ulster University, Coleraine, Northern Ireland BT52 1SA, United Kingdom. 


\section{Summary}

Scope: The aim of this study was to identify if specific regions of the human genome were sensitive to folate status by displaying changes in their DNA methylation patterns in response to continued folic acid supplementation during pregnancy.

Methods and results: Samples $(n=119)$ from a previous randomized controlled trial in pregnancy were used to compare the DNA methylation profiles of the same woman pre- versus post- folic acid intervention. Candidate genes were identified from the literature and a pilot genome wide screen of 6 women ( 3 from each of the folic acid and placebo arms of the trial). We did not observe consistent DNA methylation changes in response to folic acid intervention at any of our candidate genes (RASA4, DHFR, DHFR2, RASSF1A, EIF2C3, ATPF1). We did identify a $40 \%$ decrease in DNA methylation at the RASA4 promoter correlating with a 3.5 fold increase in its mRNA abundance in an in vitro cell culture model.

Conclusion: Continued folic acid intervention over a 22-week period did not appear to significantly influence the DNA methylation status of six candidate genes in blood samples of women compared to placebo. However, DNA methylation may play a role in the gene expression control of the RASA4 gene.

Correspondence: Dr. Anne Parle-McDermott, School of Biotechnology, Dublin City University, Dublin 9, Ireland. Email: anne.parle-mcdermott@dcu.ie

Keywords: DNA, Folic Acid, Gene Expression, Intervention, Methylation.

Abbreviations: OCM, One Carbon Metabolism; FS-DMR, Folate SensitiveDifferentially Methylated Regions; FA, folic acid. 


\section{Introduction}

DNA methylation is a mechanism used by cells in combination with histone and chromatin modifications to control gene expression. Its role in the control of gene expression is best characterised in relation to cellular differentiation and in the monoallelic expression of specific parent-of-origin genes that are referred to as imprinted regions of the genome (Klose and Bird, 2006). The process of DNA methylation is the addition of a methyl group to cytosine residues usually in the context of a $\mathrm{CpG}$. However, it is now known that methylation can occur outside the CpG context, to other DNA bases and extends beyond just a simple methyl group (Lister et al., 2009, Wu et al., 2016, Dominissini et al., 2016). Research over the last decade has revealed that the DNA methylation signatures across the genome, often referred to as the Methylome, have different associations with gene expression control depending on where in the gene they occur i.e., in the promoter region or in the body of the gene (Ball et al., 2009), and they also appear to be context specific. Despite the complexity, it is accepted that changes to gene-specific DNA methylation patterns can potentially have an impact on the expression level of a particular gene and therefore, can influence cellular phenotypes. The possibility that environmental influences such as diet and lifestyle can have an influence on DNA methylation patterns has influenced a plethora of research in this area. Furthermore, these changes can have consequences not only for individual cell lineages, but can manifest across generations.

There is convincing epidemiological data to support the 'fetal origin of adult disease' hypothesis i.e., the concept that the in utero environment can impact not only the developing embryo but also the subsequent offspring across a number of generations (Barker, 1990). Deciphering the molecular mechanism that mediates this 
phenomenon is challenging, but the modifications to DNA methylation patterns has been an attractive model. Amongst the environmental influences that have been proposed to have an impact on DNA methylation, an individual's folate status has received particular attention (Friso et al., 2017). Folate is metabolised through the One Carbon metabolism (OCM) pathway. This pathway supplies the 1C units (onecarbon) required for nucleotide synthesis, methylation reactions, cysteine through trans-sulphuration of homocysteine and it is a contributor to NADPH production (Bailey et al., 2015, Fan et al., 2014). As folate supplies the methyl groups for methylation reactions it has been proposed as one of the nutrients that could have a direct effect on the DNA methylation levels of an individual and/or their offspring. Genomic regions that are potentially sensitive to folate status are referred to here as Folate Sensitive-Differentially Methylated Regions (FS-DMR). In support of this hypothesis, a number of animal models have demonstrated that maternal diet can have trans-generational effects on the methylation patterns of the subsequent offspring (Parle-McDermott and Ozaki, 2011, Holland et al., 2016, Barua et al., 2016). Providing equivalent evidence from human studies has proven to be considerably more challenging. It is clear that the DNA methylation patterns of individuals do change as they age (Jones et al., 2015) but evidence supporting folate status having a direct impact on human DNA methylation patterns is limited. Many studies have used HPLC, labelling methods (Parle-McDermott A and Ozaki M, 2011, Friso et al., 2002, Jacob et al., 1998, Rampersaud et al., 2000) or LINE-1 methylation as a proxy for global methylation (Badiga et al., 2016), performed gene-specific analyses using known imprinted genes (Steegers-Theunissen et al., 2009, McCullough et al., 2016, Pauwels et al., 2017) or have applied Illumina Beadchip arrays (Fryer et al., 2011, Joubert et al., 2016). A study by Amarasekera et al. (2014) did identify the region 
upstream of ZFP57 as a hypomethylated FS-DMR in immune cells isolated from cord blood. Zhong et al. (2017) showed in a study of ten individuals that B-vitamins could attenuate fine-particle induced DNA methylation changes in CD4+ helper cells. Joubert et al. (2016) identified a number of FS-DMR using Illumina Beadchip arrays in the cord blood of a large newborn cohort $(\mathrm{n}=1,988)$ with known maternal folate levels. Verification of reported FS-DMR to date, remain to be confirmed in other cohorts and with alternative technical methods. None of these studies so far have utilised samples from a folic acid intervention study to identify FS-DMR.

We report here the use of a folic acid intervention trial to assess candidate FSDMRs identified from a pilot genome-wide screen and the literature.

\section{Materials and methods}

\subsection{Participants}

The genomic DNA used in this investigation was extracted using available blood samples from the Folic Acid Supplementation in the Second and Third Trimesters (FASSTT) randomized controlled trial in pregnancy, as previously published, with appropriate informed consent and ethical approval to cover the current analysis (McNulty et al., 2013, Pentieva et al., 2016). The FASSTT trial was conducted in 2006-7 and involved healthy women with uncomplicated pregnancy who were recruited at week 14 of gestation. All women in the trial had taken folic acid (FA) supplements at a dose of $400 \mu \mathrm{g} / \mathrm{d}$ during the first trimester of pregnancy. Exclusion criteria included having taken a dose of FA higher than $400 \mu \mathrm{g} / \mathrm{d}$, were taking medication that is known to interfere with folate metabolism (including aspirin, antiacids, aminopterin, pyrimethamine, phenytoin, methotrexate, sulfasalazine, phenobarbital or primidone), had undergone in vitro fertilization or had previously 
had a pregnancy affected by a neural tube defect. Women were randomly allocated to continue to receive a FA supplement of $400 \mu \mathrm{g} / \mathrm{d}$ for the remainder of their pregnancy $(n=59)$ or placebo $(n=60)$. A non-fasting blood sample was taken at the beginning of the trial i.e., at gestation week 14 (pre-intervention) and at week 36 (postintervention) $(\mathrm{n}=119)$. Plasma homocysteine, serum folate, and red-cell folate (RCF) level measurements were previously determined (McNulty et al., 2013) and available for this study.

\subsection{Genomic DNA Isolation from Buffy Coat}

Genomic DNA was isolated from frozen buffy coat samples as follows. Samples were thawed quickly in a $37^{\circ} \mathrm{C}$ water bath. A $20 \mu \mathrm{L}$ volume of proteinase $\mathrm{K}$ was added to each sample in order to homogenize the blood clots found in the samples before DNA extraction. DNA was extracted using the Qiagen ${ }^{\circledR}$ FlexiGene DNA Kit as recommended by the manufacturer. DNA concentration was determined using a Nanodrop 1000 Spectrophotometer instrument. All samples were within an $A_{260 / 280 n m}$ ratio of 1.8-2.1. Integrity of the genomic DNA was also assessed by electrophoresis on a $1 \%$ agarose gel. Extracted DNA samples were stored at $-20^{\circ} \mathrm{C}$.

\subsection{Pilot Genome-wide DNA methylation analysis}

\subsubsection{Selection of samples}

Our approach to identify potential novel Folate Sensitive-Differentially Methylated Regions (FS-DMR) was to compare DNA samples from the same individual pre- and post- intervention. From the entire FASSTT cohort, 12 samples were selected from 6 women, all of which displayed low baseline levels of RCF and serum folate prior to intervention to maximize the potential to identify FS-DMR (Table 1). Of these, 6 
samples were from 3 women in the continuation of FA supplementation arm of the trial who had the greatest response in terms of their RCF and serum folate levels postintervention compared to baseline. The remaining 6 samples were from 3 women in the placebo arm of the trial that had a decline in serum folate compared to baseline that was typical of all pregnant women in the placebo group.

\subsubsection{Methylated DNA Immunoprecipitation}

Immunoprecipitation of methylated DNA (MeDIP) and enrichment verification by qPCR is described in the Supplementary Information.

\subsubsection{Microarray analysis}

The MeDIP and Input DNA (sample without antibody) samples were processed by the Roche NimbleGen DNA Methylation Service as follows: MeDIP samples were labelled using Cy5 random nanomers, while Input DNA was labelled with Cy3 nanomers. Input and MeDIP fractions for each sample were mixed and hybridised to the array using a Precision Mixer Alignment Tool (PMAT). Each PMAT was washed and incubated at $42^{\circ} \mathrm{C}$ in a Roche Hybridisation system for 16 hours. All 12 samples were loaded into a NimbleGen MS 200 Microarray Scanner in a one Slide Magazine. Image files were extracted and processed using DEVA software. Data was returned in the form of pair files, processed peak files, Signal Map GFF files, and promoter reports.

\subsubsection{MeDIP microarray data analysis}

A number of technical and consistency filters were applied sequentially to select candidate FS-DMR from the pilot genome wide screen (Supplementary Information 
Figure 1). MeDIP microarray data was received in several raw and processed file formats, including Microsoft Excel files containing annotated information for each "peak" i.e., groups of probes across a genomic region that showed a four-fold change in DNA methylation enrichment compared to Input. Each peak consisted of a number of probes ( 4 or higher) that spanned a given genomic region. Each probe was $100 \mathrm{bp}$ in length. The cut-off enrichment peak score was set at 2.0 i.e., a DNA region scoring below this was deemed unmethylated. The criteria used for the identification of putative FS-DMR, was to compare the peak scores of the pre- versus postintervention sample in each individual and those sites that showed a consistent DNA methylation change in all three individuals in the continued FA intervention arm but not in the placebo arm of the trial would be deemed a candidate FS-DMR for verification in all samples in the FASSTT trial. Identification of putative FS-DMR from analysis of the peak fold changes would then prompt a more in-depth analysis of the raw data. A number of macros were written using Visual Basic 6.0 to aid with these comparisons.

A list of peak regions were identified that showed a consistent DNA methylation change based on peak score comparisons pre- and post-intervention in the folic acid intervention samples but not in placebo. A fold change was generated by dividing the peak score of the post-intervention sample with the peak score of the preintervention sample from the same individual. The cut-off was $\geq 1.2$ fold change in all three samples in the intervention group and $\leq 1.0$ for the same probe in all three samples in the placebo. Apart from fold differences in peak regions, an On/Off and Off/On lists were also generated by identifying peak regions that did or did not appear in the pre-intervention versus post-intervention sample following MeDIP respectively. Candidate FS-DMR identified from these analyses then underwent a more in-depth 
analysis of the probe distribution within each peak to assess whether the DNA methylation changes detected arose from the same or different probes in that peak region as the DEVA software gives the same gene name to groups of probes representing different $\mathrm{CpG}$ sites. Candidates only remained if the same $\mathrm{CpG}$ sites were differentially methylated across samples. This final analysis was carried out using the raw data on the peak-probe relationships contained in the Signal Map GFF files. A False Discovery Rate was not applied as we did not expect a large number of false positives following statistical and technical filtering.

\subsection{RASA4 gene expression and DNA methylation analysis in a cell culture model}

\subsubsection{De-methylation cell culture conditions}

Preliminary experiments were performed in HEK 293 (Human Embryonic Kidney) cells to assess the cytotoxicity of 5-azacytidine at different concentrations over a 7day time period and to ensure that the cells remained in log phase throughout the experiment. A $5 \mu \mathrm{M}$ concentration of 5-azacytidine was determined to be the optimal concentration as assessed by a crystal violet assay (data not shown). HEK 293 cells were cultured in T75 flasks in Dulbecco's Modified Eagle Medium (DMEM, Gibco) supplemented with $10 \%(\mathrm{v} / \mathrm{v})$ foetal bovine serum, $1 \%(\mathrm{v} / \mathrm{v})$ L-glutamine (SigmaAldrich) and $1 \%$ (v/v) sodium pyruvate (Sigma-Aldrich) and allowed to attach prior to exposure to 5-azacytidine. Cells were exposed to $5 \mu \mathrm{M}$ 5-azacytidine or acetic acid alone over a 7-day period with daily media changes due to the short half-life of the drug (Komashko and Farnham, 2010). Nucleic acid extractions were performed on day 7. The experiment was performed on two separate occasions. 


\subsubsection{RASA4 gene expression analysis by RT-qPCR}

Gene expression was assessed using Reverse Transcription-quantitative PCR (RTqPCR). RNA was extracted from 5-azacytidine treated HEK 293 cells using Bioline's Isolate II RNA mini kit. Integrity of the RNA was verified by electrophoresis on a $1 \%$ agarose gel and stained with ethidium bromide. The RNA was treated with DNase I (Sigma-Aldrich) prior to conversion to cDNA using a Bioline Superscript kit

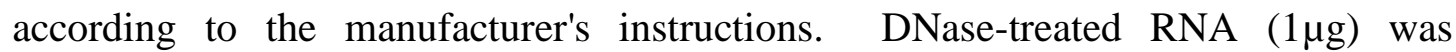
transferred to a tube containing a mix of $2 \mu \mathrm{l}$ random hexamers $(50 \mathrm{ng} / \mu \mathrm{l})$ and $4 \mu \mathrm{l}$ oligo-DT $(270 \mathrm{ng} / \mu \mathrm{l})$. After incubation for $70^{\circ} \mathrm{C}$ for 5 minutes, samples were cooled on ice and added to a reaction containing $4 \mu$ l Reaction Buffer $(5 x), 1 \mu l$ RiboSafe RNase inhibitor $(40 \mathrm{u} / \mu \mathrm{l}) \quad 1 \mu \mathrm{l}$ Bioline Bioscript reverse transcriptase enzyme $(200 \mathrm{u} / \mu \mathrm{l}), 1 \mu \mathrm{l} \mathrm{dNTPs}(10 \mathrm{mM})$, and $1.5 \mu \mathrm{l}$ nuclease-free water. Samples were incubated under the following programme: 10 minutes, $25^{\circ} \mathrm{C}$; 60 minutes, $42{ }^{\circ} \mathrm{C}$; and 15 minutes, $70^{\circ} \mathrm{C}$.

An intron spanning RT-qPCR assay was used to verify the elimination of any potentially contaminating genomic DNA. All RT-qPCR reactions were carried out on the Roche 480 Lightcycler machine with assays designed by the Universal ProbeLibrary Design Centre. Each reaction contained a 1/10 dilution of the supplied and recommended probe, $2 \mathrm{x}$ Probe Master, $2.5 \mathrm{mM} \mathrm{MgCl} 2$, and $1 \mu 1 \mathrm{cDNA}$.

\subsubsection{RASA4 DNA methylation analysis}

DNA was extracted from HEK 293 cells using the Qiagen® FlexiGene DNA Kit as recommended by the manufacturer. DNA was RNase-treated with $25 \mu \mathrm{g}$ Ribonuclease (Sigma-Aldrich) for 30 minutes at $37^{\circ} \mathrm{C}$ and was then ethanol precipitated with $0.3 \mathrm{M}$ sodium acetate and 2 volumes of isopropanol. DNA was 
quantified and checked for quality as described above and subsequently prepared for site-specific DNA methylation analysis as described below.

DNA for SMART-MSP underwent sodium bisulfite treatment using the Qiagen ${ }^{\circledR}$ Epitect kit according to the manufacturer's instructions except that $1 \mu \mathrm{g}$ of DNA was used and the final elution was in a $100 \mu \mathrm{l}$ volume of molecular biology grade water.

\subsection{DNA methylation analysis of candidate FS-DMR}

Candidate FS-DMR were identified from the pilot genome-wide DNA methylation analysis (Section 2.3), were selected from the literature (Fryer et al., 2011; ParleMcDermott et al., 2011; Vineis et al., 2011) and from the OCM pathway. Candidates were selected following a literature survey (Parle-McDermott et al., 2011) to identify those gene-specific sites that had previously shown a DNA methylation change that was potentially driven by changes in folate status. These included RASSFIA (Ras associated domain family member 1 alpha), EIF2C3 (Eukaryotic translation initiation factor 2C, 3) and ATPF1 (ATPase synthase $\mathrm{H}^{+}$transporting, mitochondrial Fo complex, subunit B1). Two enzymes from OCM were also included; DHFR (Dihydrofolate reductase) and DHFR2 (formerly known as DHFRL1: Dihydrofolate folate reductase like-1). The DNA methylation status of candidate FS-DMR were assessed in the FASSTT cohort using either Sensitive Melting Analysis after Real Time-Methylation Specific PCR (SMART-MSP) analysis or Methylation SensitiveHigh Resolution Melting (MS-HRM) analysis on the Roche Lightcycler $\AA^{\circledR} 480$ instrument.

\subsubsection{SMART-MSP}


SMART-MSP assays were designed and performed according to Kristensen et al (2008). The target region primer sequences and optimized annealing temperatures were as follows: RASA4 Forward 5'-CGTGGAGGGGAAGAACCT-3', Reverse 5'TCCACCTTCACGATGCAGTA-3', Tm 56 ${ }^{\circ} \mathrm{C}$; DHFR Forward 5'GAGGGTTTCGTTTCGTTCG-3', Reverse 5'CAAATAAACCCTAACGCTACAACG-3', Tm 54 ${ }^{\circ} \mathrm{C} ;$ DHFR2 Forward 5'GGGTTAGGGTTAAAGCGATTTTCGT-3', Reverse 5'AAACAAAAACCGCACAAACGCG-3', Tm $58^{\circ} \mathrm{C}$. Each assay was designed to only amplify methylated DNA following bisulfite treatment. The COL2Al primer sequences were as previously described (Kristensen et al., 2008) and are designed to assess the amount of amplifiable bisulfite converted DNA in the sample regardless of its methylation status $\left(\operatorname{Tm} 63^{\circ} \mathrm{C}\right)$. The amplification and melting conditions were optimized using 100\% and 0\% DNA methylation standards (Qiagen®). Genomic DNA was bisulfite treated using the Qiagen Epitect Fast Bisulfite conversion kit. A $2.5 \mu \mathrm{L}$ volume (25 ng) of bisulfite treated DNA (theoretical amount) was used per reaction, giving a final volume of $10 \mu \mathrm{L}$. A positive $100 \%$ methylated control and negative template control using $2.5 \mu \mathrm{L} \mathrm{H}_{2} \mathrm{O}$ instead of DNA was also included. All samples were carried out in duplicate. Template DNA was initially denatured at $95^{\circ} \mathrm{C}$ for $10 \mathrm{~min}$, followed by 45 amplification cycles, followed by high-resolution melting analysis on the Lightcycler® 480 . Each cycle consisted of template denaturation $\left(95^{\circ} \mathrm{C}\right.$ for $\left.10 \mathrm{~s}\right)$, primer annealing (Tm for $\left.15 \mathrm{~s}\right)$ and extension $\left(72^{\circ} \mathrm{C}\right.$ for $\left.15 \mathrm{~s}\right)$. This was followed by high-resolution melting analysis. High-resolution melting settings consisted of $95^{\circ} \mathrm{C}$ for $1 \mathrm{~min}, 40^{\circ} \mathrm{C}$ for $1 \mathrm{~min}, 70^{\circ} \mathrm{C}$ for $5 \mathrm{~s}$ and continuous acquisition to $95^{\circ} \mathrm{C}$ (ramp rate $0.02{ }^{\circ} \mathrm{C} / \mathrm{s}$ ), followed by cooling at $40^{\circ} \mathrm{C}$ for $10 \mathrm{~s}$. Crossing point (Cp) values and melting temperature for the DNA samples were assigned 
automatically by the Lightcycler ${ }^{\circledR} 480$ Software. Cp values were averaged and methylation values were quantified using the $2^{(-\Delta \Delta \mathrm{Cp})}$ quantification approach (Kristensen et al., 2008).

\subsubsection{MS-HRM}

Genomic DNA used for MS-HRM assays was bisulfite treated using Imprint ${ }^{\circ}$ DNA Modification Kit (Sigma-Aldrich) according to the manufacturers' instructions. A 1 $\mu \mathrm{L}$ volume of bisulfite treated DNA (500 ng concentration) was used per reaction, giving a final volume of $10 \mu \mathrm{L}$. A negative-template control using $1 \mu \mathrm{L} \mathrm{H}_{2} \mathrm{O}$ instead of DNA was also included. Template DNA was initially denatured at $95^{\circ} \mathrm{C}$ for 10 min, followed by 45 amplification cycles, followed by high-resolution melting analysis on the Lightcycler® 480. Each cycle consisted of template denaturation $\left(95^{\circ} \mathrm{C}\right.$ for $\left.10 \mathrm{~s}\right)$, primer annealing (Tm for $\left.15 \mathrm{~s}\right)$ and extension $\left(72^{\circ} \mathrm{C}\right.$ for $\left.15 \mathrm{~s}\right)$. This was followed by high-resolution melting analysis. High-resolution melting settings consisted of $95^{\circ} \mathrm{C}$ for $1 \mathrm{~min}, 40^{\circ} \mathrm{C}$ for $1 \mathrm{~min}, 70^{\circ} \mathrm{C}$ for $5 \mathrm{~s}$ and continuous acquisition to $95^{\circ} \mathrm{C}$ (ramp rate $0.02{ }^{\circ} \mathrm{C} / \mathrm{s}$ ), followed by cooling at $40^{\circ} \mathrm{C}$ for $10 \mathrm{~s}$. Melting temperature for the DNA samples were assigned automatically by the Lightcycler $\AA$ 480 Software.

\subsubsection{Statistical analyses}

For each DNA methylation assay, the difference in percentage of methylation in the pre- versus post-intervention sample was calculated for each individual. The assays were suitable for detecting changes of at least $10 \%$ or greater and therefore, individuals were placed in one of three categories: Up $(>10 \%$ increase in methylation); Down $(<10 \%$ decrease in methylation); No Change $(<+$ or $-10 \%)$. 
Tests for significance across categories were performed using a single-factor analysis of variance, ANOVA from Excel's Analysis Toolpack add-in.

\section{Results}

\subsection{Pilot genome wide screen identifies the RASA4 gene as a candidate human FS-DMR}

We performed a genome-wide DNA methylation analysis in a subset of the FASSTT samples ( $n=6$ individuals) in a bid to identify candidate FS-DMRs that would be subsequently screened in the entire cohort. To minimize the amount of DNA methylation 'noise' due to non-folate related factors such as other environmental stimuli and individual genetic variation (McRae et al., 2014), we compared the DNA methylation profile of the same individual pre- and post- folic acid intervention (FA 1-3) or placebo (Table 1) to identify putative FS-DMR. As expected, the folate status of those women who continued to take folic acid supplements from gestational week 14 to 36 improved in line with what was previously reported for the rest of the cohort (McNulty et al., 2013), while those women taking placebo showed a drop in plasma folate status as is typically observed during pregnancy (Chanarin et al., 1968; Hall et al., 1976) and as previously reported for the rest of the cohort (McNulty et al., 2013) (Table 1).

We applied Methylated DNA Immunoprecipitation (MeDIP) to all 12 samples (2 samples from each individual (pre- and post-intervention)). The samples underwent quantitative-PCR (qPCR) to ensure that the MeDIP and subsequent whole genome amplification ultimately yielded DNA that was enriched for the methylated fraction of the genome in a given sample in comparison to Input DNA (i.e., not immunoprecipitated). On average the MeDIP DNA was enriched 3.41 fold as 
assessed by the H19 methylated DNA assay, and a decrease of 25 fold in the unmethylated DNA as assessed by the $H 3 b$ unmethylated DNA assay. Following these quality control measures, the 12 samples plus their Input DNA equivalents were sent to Nimblegen and hybridized to the Nimblegen Delux 2.1M promoter array. This promoter array can assess the DNA methylation status of up to $28,266 \mathrm{CpG}$ islands in close proximity to gene and miRNA promoters. Nimblegen also performed a similar QC process prior to hybridization.

We used a data analysis pipeline to identify candidate FS-DMR from the MeDIP analysis as described in Supplementary Information Figure 1 and in the Materials and Methods section. Our overall assessment of the DNA methylation profiles generated using the MeDIP method was that although methylation differences were detected in the pre- and post-intervention samples from the same individual in both the FA intervention and the placebo groups, there was very little consistency in the specific CpG sites that showed methylation differences. We initially derived a list of potential FS-DMR sites in the promoter regions of 19 genes based on the peak score fold differences but the standard deviation and subsequent analysis of the individual peak scores reduced this number to 5 . Of these 5 , ultimately 4 were also rejected based on further analysis of the probes within the peak regions. While the DEVA software assigns the same gene for a number of overlapping probes, we found that analysis of the raw data showed that the specific probes within the 4 candidate FS-DMR were different across our three FA intervention samples and therefore, these sites were not considered consistent. The one remaining candidate FS-DMR, Ras $p 21$ protein activator (RASA4; NM_001079877) promoter, was derived from the 'On/Off' list i.e., a gene promoter region that was considered methylated pre-intervention and then lost its methylation status post-intervention ('On/Off'). RASA4 showed a mean 
fold methylation enrichment score of 7.27 in all three individuals (SD 1.49) in the FA pre-intervention samples and complete loss of methylation at the same promoter region after intervention (i.e., a score <2.0). The same promoter showed no change in methylation status in the placebo group pre- and post-intervention (average 0.96 $(\mathrm{SD} 0.27))$

\subsection{Loss of DNA methylation at the RASA4 promoter correlates with an increase in gene expression in HEK293 cells exposed to 5- azacytidine}

The relevance of DNA methylation status at the promoter of RASA4 was undertaken by assessing whether loss of global DNA methylation correlates with a gene specific loss of DNA methylation and with an increase in the abundance of RASA4 mRNA. We employed a cell culture model by exposure of HEK293 cells to 5-azacytidine resulting in passive global DNA de-methylation through inhibition of DNA methyltransferases (Schneider-Stock et al., 2005). Preliminary experiments identified $5 \mu \mathrm{M}$ of 5 -azacytidine as the highest dose of the drug that the cells can tolerate while still maintaining the capacity to double over a 7-day period. This effectively allows progressive passive DNA de-methylation at each cell doubling. DNA and RNA were extracted at the end of the 7-day exposure and RASA4 specific DNA methylation and gene expression analyses were performed. Comparison of the level of DNA methylation (at sites between $-158 \mathrm{bp}$ and $-81 \mathrm{bp}$ relative to the transcription start site of the RASA4 promoter) in the promoter of RASA4 showed a loss of methylation in the $5 \mu \mathrm{M}$ 5-azacytidine exposed cells compared to the control $(0 \mu \mathrm{M})$ (Fig. 1a) using SMART-MSP. This RASA4 DNA de-methylation also resulted in an increase in gene expression level as assessed by RT-qPCR (Fig. 1b). This suggests that specific DNA 
methylation sites at the RASA4 promoter have a direct impact on the gene expression level of this gene and therefore, DNA methylation changes at this putative FS-DMR is likely to have functional biological relevance.

\subsection{DNA methylation analysis of candidate FS-DMR in the FASSTT}

\section{cohort}

Our pilot genome wide screen in a subset of the FASSTT samples and our subsequent cell culture analyses identified RASA4 as a candidate FS-DMR. We also identified a number of additional potential FS-DMR from the literature (Fryer et al., 2011; ParleMcDermott et al., 2011; Vineis et al., 2011) and these included RASSF1A (Ras associated domain family member 1 alpha), EIF2C3 (Eukaryotic translation initiation factor 2C, 3) and ATPF1 (ATPase synthase $\mathrm{H}^{+}$transporting, mitochondrial Fo complex, subunit B1). In addition, DHFR (Dihydrofolate reductase) and DHFR2 (formerly known as DHFRL1: Dihydrofolate folate reductase like-1) formed part of the final candidate FS-DMR list given their central role in OCM and being the only enzymes capable of reducing folic acid (Bailey 1995; McEntee et al., 2011; Anderson et al., 2011). We designed either a MS-HRM or a SMART-MSP assay to assess the DNA methylation status of specific $\mathrm{CpG}$ sites in the proximal promoters of each putative FS-DMR pre- versus post-intervention for each individual. We chose a $>10 \%$ change in the methylation status as the cut-off, given the limits of detection of our assays within this range and the lack of clarity in the field as to the relevance of DNA methylation of less than $10 \%$.

RASA4, DHFR and DHFR2 were each examined by SMART-MSP and the pre- versus post-intervention methylation levels compared in each individual (Fig. 2). 
The majority of individuals (88\%) were unmethylated for RASA4 and showed no change in methylation status in the post- versus pre-intervention samples. There was no distinction between the FA intervention and the placebo group in this regard. The small percentage of individuals that did show a methylation change showed either a variable increase or decrease in percentage methylation and again, there was no difference in the number of individuals from the FA intervention group compared to the placebo group. DHFR2 was unmethylated in all samples tested, while DHFR showed a low level of methylation (10-20\%) for the majority of samples tested (Fig. 2) but similarly to RASA4, most individuals showed no change in methylation postintervention and those that did were variable and did not differentiate between the FA intervention and placebo groups. Our analysis of RASSF1A, EIF $2 C 3$ and ATPF1 by MS-HRM showed that the regions examined were unmethylated in all of the samples examined by comparison to DNA methylation standards. In summary, our sitespecific DNA methylation analyses did not confirm our six candidates as definitive FS-DMR. 


\section{Discussion}

Our genome wide DNA methylation analysis on a subset of participants from the FASSTT trial (pre- versus post- intervention with folic acid) identified the promoter of RASA4 as a novel candidate FS-DMR but we were unable to confirm this in the rest of the cohort. We did however, demonstrate that methylation loss at the RASA4 promoter correlates with an increase in gene expression levels in HEK293 cells, indicating the functional relevance of DNA methylation at the control region of this gene (Fig. 1). However, we do acknowledge that demonstration of DNA methylation control in a cell line may not be conserved in other tissues. RASA4 is encoded on chromosome 7 and its protein product is a member of the GAP1 family of Ras GTPase-activating proteins (MIM: 607943) (Lockyer et al., 2001). It plays a role in the regulation of Ras signalling at its various subcellular locations (Lockyer et al., 2001; Bivona et al., 2003). Hypermethylation of RASA4 has been correlated with poor prognosis in juvenile myelomonocytic leukemia (Poetsch et al., 2014). As our confirmatory DNA methylation analysis in all the FASSTT samples showed that the majority of samples were unmethylated and therefore, definitive conclusions on the relevance of the RASA4 as a possible FS-DMR could not be made. We suggest testing the response of RASA4 DNA methylation to folate status and/or folic acid intervention in other cohorts before a final conclusion can be made. Our site-specific DNA methylation analysis of RASSF1A, EIF2C3, ATPF1, DHFR and DHFR2 failed to provide evidence that the control regions of these genes are sensitive to folate status.

Our analyses of the same individuals pre- and post- intervention with folic acid for 22 weeks, did not identify FS-DMR sites in blood samples of pregnant women. We do acknowledge that a more site-specific, detailed methodology such as bisulphite Next Generation Sequencing (NGS) coupled with pyrosequencing and 
larger study numbers may have yielded contrasting results to the negative findings that we achieved with MeDIP microarray and the melting PCR methods that we employed in this study. It is also possible that cord blood DNA may be more sensitive to methylation changes than the adult DNA samples that we examined in this manuscript due to the re-programming of DNA methylation patterns that occurs during development (Cedar and Bergman, 2012). Moreover, a parallel study in the same cohort did examine a different set of candidate FS-DMR in the cord blood DNA samples (rather than the mother's DNA) and did identify differences in methylation patterns in the cords exposed to continued folic acid supplementation compared to placebo (Caffrey et al., 2018). Another limitation is that both the placebo and FA intervention groups were taking a FA supplement up to the first trimester of pregnancy and therefore, the baseline folate status may have been too high to observe any meaningful folate-mediated changes. Despite the limitations of our study, a search of the literature reveals a high level of inconsistency in the field in relation to the reported impact of folate status on methylation status in various gene targets (Parle-McDermott and Ozaki, 2011). It is good experimental laboratory practice to confirm a result with an alternative technique and many studies in this area have not done this (Fryer et al., 2011; Joubert et al., 2016). Others reported significant increases or decreases in DNA methylation at specific sites, but with marginal percentage changes (Steegers-Theunissen et al., 2009; McCullough et al., 2016; Pauwels et al., 2017), which raises the question: What constitutes a biologically significant change in DNA methylation? Answering this will require a detailed analysis of which $\mathrm{CpG}$ sites have functional relevance for the control of the expression of a given gene and extensive knowledge on this has not been generated to date. In other words, small changes in percentage DNA methylation may have 
functional relevance but this has not been proven so far and needs to be elucidated on a gene-by-gene basis. Moreover, the position of the methylation site relative to the transcription start site is highly relevant for its potential functional significance in relation to gene control, and again requires a detailed investigation on a gene-by-gene basis.

The biological plausibility of folate status having a direct impact on DNA methylation is strong, given that OCM is the provider of the methyl group through Sadenosylmethionine (SAM). However, as we previously noted (Parle-McDermott and Ozaki, 2011), reported methylation changes in response to folate restriction show both increased and decreased levels indicating that the response is complex and it is not just a question of SAM supply. There are numerous studies that indicate that markers of folate status do correlate with global measures of DNA methylation including HPLC measurements of methylated cytosines abundance (Friso et al., 2002) and LINE-1 element methylation (Badiga et al., 2016). This indicates that global DNA methylation per se is affected but it remains to be proven whether this translates into consistent site-specific DNA methylation changes that have actual biological relevance. It is notable that a recent study observed that environmental influences on global DNA methylations patterns are minor relative to the effects of genetic differences between individuals (McRae et al., 2014).

In conclusion, our analyses of human blood samples from a folic acid intervention trial did not find folate sensitive sites of large effect. Further studies are required to assess whether FS-DMR are a feature of the human genome but closer attention needs to be paid to the molecular relevance of such changes and whether they have any impact on cellular function. 


\section{Acknowledgements}

This study was supported by funding from a Health Research Board of Ireland grant (to A Parle-McDermott) (HRA_PHS/2010/20), and a DCU Daniel O'Hare Ph.D scholarship (to A Harrison).

None of the authors have a conflict of interest.

A.H. contributed to the study design, performed the pilot genome wide screen, the RASA4 screening and in vitro cell culture experiments and contributed to data interpretation and drafts of the manuscript. K.P. and H.M. contributed to the study design and data interpretation, provided samples and metabolite data, and commented on drafts of the manuscript. M.O. performed the DNA extractions for all the samples in the FASSTT study; designed and executed methylation assays for five out of the six genes; contributed to data interpretation and figure preparation. A.P.M. designed and supervised the study, contributed to data interpretation and analysis and wrote the first draft of the manuscript. 


\section{References}

AMARASEKERA, M., MARTINO, D., ASHLEY, S., HARB, H., KESPER, D., STRICKLAND, D., SAFFERY, R. \& PRESCOTT, S. L. 2014. Genome-wide DNA methylation profiling identifies a folate-sensitive region of differential methylation upstream of ZFP57-imprinting regulator in humans. FASEB J, 28, 4068 - 4076.

ANDERSON, D.D., QUINTERO, C.M., STOVER, P.J. 2011. Identification of a de novo thymidylate biosynthesis pathway in mammalian mitochondria. Proc Natl Acad Sci USA. 108(37): 15163 - 15168.

BADIGA, S., SIDDIQUI, N. R., MACALUSO, M., JOHANNING, G. L. \& PIYATHILAKE, C. J. 2016. Homocysteinemia is associated with a lower degree of PBMC LINE1 methylation and a higher risk of CIN $2+$ in the US postfolic acid fortification era. Nutr Cancer, 68, 446 - 455.

BAILEY, L. N., STOVER, P. J., MCNULTY, H., FENECH, M. F., GREGORY III, J. F., MILLS, J. L., PFEIFFER, C. M., FAZILI, Z., ZHANG, M., UELAND, P. M., MOLLOY, A. M., CAUDILL, M. A., SHANE, B., BERRY, R. J., BAILEY, R. L., HAUSMAN, D. B., RAGHAVAN, R. \& RAITEN, D. J. 2015. Biomarkers of Nutrition for Development- Folate Review. J Nutr, Supplement, S1 - S45.

BAILEY, L.N. e. 1995. Folate in Health and Disease. New York: Marcel Dekker Inc.

BALL, M. P., LI, J. B., GAO, Y., LEE, J.-H., LEPROUST, E. M., PARK, I.-H., XIE, B., DALEY, G. Q. \& CHURCH, G. M. 2009. Targeted and genome-scale strategies reveal gene-body methylation signatures in human cells. Nat Biotechnol, 27, 361 368.

BARKER, D. J. 1990. The fetal and infant origins of adult disease. BMJ, 301, 1111.

BARUA, S., KUIZON, S., BROWN, W. T. \& JUNAID, M. A. 2016. DNA Methylation profiling at single-base resolution reveals gestational folic acid supplementation influences the epigenome of mouse offspring cerebellum. Front Neurosci, 10, 1 - 14.

BIVONA, T.G., DE CASTRO, I.P., AHEARN, I.M., GRANA, T.M., CHIU, V.K., LOCKYER, P.J., CULLEN, P.J., PELLICER, A., COX, A.D., PHILIPS, M.R. 2003. Phospholipase $\mathrm{C}$ activates Ras on the Golgi apparatus by means of RasGRP1. Nature, 424, $694-698$.

CAFFREY, A., IRWIN, R.E., MCNULTY, H., STRAIN, J.J., LEES-MURDOCK, D.J., MCNULTY, B.A., WARD, M., WALSH, C.P., PENTIEVA, K. 2018. Gene-specific DNA methylation in newborns in response to folic acid supplementation during the second and third trimesters of pregnancy: epigenetic analysis from a randomized controlled trial. Am J Clin Nutr, 107, 566 - 575.

CEDAR, H., BERGMAN, Y. 2012. Programming of DNA Methylation Patterns. Annu Rev Biochem, 81, 97 - 117.

CHANARIN, I., ROTHMAN, D., WARD, A., PERRY, J. 1968. Folate status and requirement in pregnancy. $B M J, 2,390-394$.

DOMINISSINI, D., NACHTERGAELE, S., MOSHITCH-MOSHKOVITZ, S., PEER, E., KOL, N., BEN-HAIM, M. S., DAI, Q., DI SEGNI, A., SALMON-DIVON, M., ClARK, W. C., ZHENG, G., PAN, T., SOLOMON, O., EYAL, E., HERSHKOVITZ, V., HAN, D., DORE, L. C., AMARIGLIO, N., RECHAVI, G. \& HE, C. 2016. The dynamic N1- methyladenosine methylome in eukaryotic messenger RNA. Nature, 530, 441 - 446.

FAN J, Y. J., KAMPHORST JJ, SHLOMI T, THOMPSON CB, RABINOWITZ JD 2014. Quantitative flux analysis reveals folate-dependent NADPH production. Nature, 510, $298-302$.

FRISO, S., CHOI, S. W., GIRELLI, D., MASON, J. B., DOLNIKOWSKI, G. G., BAGLEY, P. J., OLIVIERI, O., JAQUES, P. F., ROSENBERG, I. H., CORROCHER, R. \& SELHUB, J. 2002. A common mutation in the 5,10-methylenetetrahydrofolate 
reductase gene affects genomic DNA methylation through an interaction with folate status. Proc Natl Acad Sci U S A, 99, 5606 - 5611.

FRISO, S., UDALI, S., DE SANTIS, D. \& CHOI, S. W. 2017. One Carbon Metabolism and Epigenetics. Mol Aspects Med, 54, 28 - 36.

FRYER, A.A., EMES, R.D., ISMAIL, K.M., HAWORTH, K.E., MEIN, C., CARROLL, W.D. \& FARRELL, W.E. 2011. Quantitative, high resolution epigenetic profiling of CpG loci identifies associations with cord blood plasma homocysteine and birth weight in humans. Epigenetics, 6, 86-94.

HALL, M.H., PIRANI, B.B., CAMPBELL, D. The cause of the fall in serum folate in normal pregnancy. BJOG, 83, 132 - 136.

HOLLAND, M. L., LOWE, R., CATON, P. W., GEMMA, C., CARBAJOSA, G., DANSON, A. F., CARPENTER, A. A. M., LOCHE, E., OZANNE, S. E. \& RAKYAN, V. K. 2016. Early-life nutrition modulates the epigenetic state of specific rDNA genetic variants in mice. . Science, 353, 495 - 498.

JACOB, R. A., GRETZ, D. M., TAYLOR, P. C., JAMES, S. J., POGRIBNY, I. P., MILLER, B. J., HENNING, S. M. \& SWENDSEID, M. E. 1998. Moderate folate depletion increases plasma homocysteine and decreases lymphocyte DNA methylation in postmenopausal women. $J$ Nutr, 128, 1204 - 1212.

JONES, M. J., GOODMAN, S. J. \& KOBOR, M. S. 2015. DNA methylation and healthy human aging. Aging Cell, 14, 924 - 932.

JOUBERT, B. R., DEN DEKKER, H. T., FELIX, J. F., BOHLIN, J., LIGTHART, S., BECKETT, E., TIEMEIER, H., VAN MEURS, J. B., UITTERLINDEN, A. G., HOFMAN, A., HABERG, S. E., REESE, S. E., PETERS, M. J., ANDREASSEN, B. K., STEEGERS, E. A. P., NILSEN, R. M., VOLlSET, S. E., MIDTTUN, O., UELAND, P. M., FRANCO, O. H., DEHGHAN, A., DE JONGSTE, J. C., WU, M. C., WANG, T., PEDDADA, S. D., JADDOE, V. W. V., NYSTAD, W., DUIJTS, L. \& LONDON, S. J. 2016. Maternal plasma folate impacts differential DNA methylation in an epigenome-wide meta-analysis of newborns. Nat Commun, 7, 10577.

KLOSE, R. J. \& BIRD, A. P. 2006. Genomic DNA methylation: the mark and its mediators. Trends Biochem Sci, 31, 89 - 97.

KOMASHKO VM \& FARNHAM PJ 2010. 5-azacytidine treatment reorganizes genomic histone modification patterns. Epigenetics, 5, 229-240.

KRISTENSEN, L.S., MIKESKA, T., KRYPUY, M., DOBROVIC, A. 2008. Sensitive Melting Analysis after Real Time-Methylation Specific PCR (SMART-MSP): highthroughput and probe-free quantitative DNA methylation detection. Nucleic Acids Res, 36(7), e42.

LISTER, R., PELIZZOLA, M., DOWEN, R. H., HAWKINS, R. D., HON, G., TONTIFILIPPINI, J., NERY, J. R., LEE, L., YE, Z., NGO, Q. M., EDSALL, L., ANTOSIEWICZ-BOURGET, J., STEWART, R., RUOTTI, V., MILLAR, A. H., THOMSON, J. A., REN, B. \& ECKER, J. R. 2009. Human DNA methylomes at base resolution show widespread epigenomic differences. Nature, 462, 315 - 322.

LOCKYER, P.J., KUPZIG, S. CULLEN, P.J. 2001. CAPRI regulates $\mathrm{Ca}(2+)$-dependent inactivation of the Ras-MAPK pathway. Current Biology, 11(12), 981 - 986.

MCENTEE, G., MINGUZZI, S. O'BRIEN, K., BEN LARBI, N., LOSCHER, C., O'FAGAIN, C., PARLE-MCDERMOTT, A. 2011. The former annotated human pseudogene dihydrofolate reductase-like 1 (DHFRL1) is expressed and functional. Proc Natl Acad Sci USA. 108(37): 15157 - 15162.

MCCULlOUGH, L. E., MILLER, E. E., MENDEZ, M. A., MURTHA, A. P., MURPHY, S. K. \& HOYO, C. 2016. Maternal B vitamins: effects on offspring weight and DNA methylation at genomically imprinted domains. Clin Epigenetics, $8,8$.

MCNULTY, B., MCNULTY, H., MARSHALL, B., WARD, M., MOLLOY, A. M., SCOTT, J. M., DORNAN, J. \& PENTIEVA, K. 2013. Impact of continuing folic acid after the first trimester of pregnancy: findings of a randomized trial of Folic Acid Supplementation in the Second and Third Trimesters. Am J Clin Nutr, 98, 92-98. 
MCRAE, A.F., POWELL, J.E., HENDERS, A.K., BOWDLER, L., HEMANI G., SHAH S., PAINTER, J.N., MARTIN, N.G., VISSCHER, P.M., MONTGOMERY, G.W. 2014. Contribution of genetic variation to transgenerational inheritance of DNA methylation. Genome Biology, 15, R73.

PARLE-MCDERMOTT A \& OZAKI M 2011. The impact of nutrition on differential methylated regions of the genome. Adv Nutr, 2, 463-471.

PAUWELS, S., GHOSH, M., DUCA, R. C., BEKAERT, B., FRESON, K., HUYBRECHTS, I., LANGIE, S. A., KOPPEN, G., DEVLIEGER, R. \& GODDERIS, L. 2017. Maternal intake of methyl-group donors affects DNA methylation of metabolic genes in infants. Clin Epigenetics, 9, 16.

PENTIEVA, K., SELHUB, J., PAUL, L., MOLlOY, A. M., MCNULTY, B., WARD, M., MARSHALL, B., DORNAN, J., REILLY, R., PARLE-MCDERMOTT, A., BRADBURY, I., OZAKI, M., SCOTT, J. M. \& MCNULTY, H. 2016. Evidence from a Randomized Trial That Exposure to Supplemental Folic Acid at Recommended Levels During Pregnancy Does Not Lead to Increased Unmetabolized Folic Acid Concentrations in Maternal or Cord Blood. J Nutr, 146, 494-500.

POETSCH, A.R., LIPKA, D.B., WITTE, T., ClAUS, R., NOLLKE, P., ZUCKNICK, M., OLK-BATZ, C., FLUHR, S., DWORZAK, M., DE MOERLOOSE, B., STARY, J., ZECCA, M., HASLE, H., SCHMUGGE, M., VAN DEN HEUVEL-EIBRINK, M.M., LOCATELLI, F., NIEMEYER, C.M., FLOTHO, C., PLASS, C. 2014. RASA4 undergoes DNA hypermethylation in resistant juvenile myelomonocytic leukemia. Epigenetics, 9(9), 1252 - 1260.

RAMPERSAUD, G. C., KAUWELL, G. P., HUTSON, A. D., CERDA, J. J. \& BAILEY, L. N. 2000. Genomic DNA methylation decreases in response to moderate folate depletion in elderly women. Am J Clin Nutr, 72, 998 - 1003.

SCHNEIDER-STOCK, R., DIAB-ASSEF, M., ROHRBEC, A., FOLTZER-JOURDAINNE, C., BOLTZE C., HARTIG, R., SCHONFELD, P., ROESSNER A., GALIMUHTASIB H. 2005. 5-Aza-cytidine is a potent inhibitor of DNA methyltransferase $3 \mathrm{a}$ and induces apoptosis in HCT-116 colon cancer cells via Gadd45- and p53dependent mechanisms. J Pharmacol Exp Ther 312(2), 525 - 536.

STEEGERS-THEUNISSEN, R. P., OBERMANN-BORST, S. A., KREMER, D., LINDEMANS, J., SIEBEL, C., STEEGERS, E. A., SLAGBOOM, P. E. \& HEIJMANS, B. T. 2009. Periconceptional maternal folic acid use of 400 microg per day is related to increased methylation of the IGF2 gene in the very young child. PLoS One, 4, e7845.

VINEIS, P., CHUANG, S.C., VAISSIERE, T., CUENIN, C., RICCERI, F., Genair-EPIC COLLABORATORS, JOHANSSON, M., UELAND, P., BRENNAN, P., HERCEG, Z. 2011. DNA methylation changes associated with cancer risk factors and blood levels of vitamin metabolites in a prospective study. Epigenetics, 6(2), 195 - 201.

WU, P. T., WANG, T., SEETIN, M. G., YONGQUAN, L., ZHU, S., LIN, K., LIU, Y., BYRUM, S. D., MACKINTOSH, S. G., M., Z., TACKETT, A., WANG, G., HON, L. S., FANG, G., SWENBERG, J. A. \& XIAO, A. Z. 2016. DNA methylation on N6adenine in mammalian embryonic stem cells. Nature, 532, 329 - 333.

ZHONG, J., KARLSSON, O., WANG, G., LI, J., GUO, Y., LIN, X., ZEMPLENYI, M., SANCHEZ-GUERRA, M., TREVISI, L., URCH, B., SPECK, M., LIANG, L., COULL, B. A., KOUTRAKIS, P., SILVERMAN, F., GOLD, D. R., WU, T. \& BACCARELLI, A. A. 2017. B vitamins attenuate the epigenetic effects of ambient fine particles in a pilot human interventional trial. Proc Natl Acad Sci U S A, 114, $3503-3508$. 
Figure 1. RASA4 promoter methylation and gene expression in response to 5azacytidine in HEK293 cells.

(A) DNA methylation at -185 to -58 bp relative to the TSS in the RASA4 promoter was assessed by a SMART-MSP assay and confirms that HEK293 treatment with 5 $\mu \mathrm{M} 5$ 'azacytidine over 7 days resulted in passive de-methylation $(\mathrm{p}=0.009)$ at this site. (B) 5-azacytidine treatment resulted in an increase in RASA4 mRNA level as assessed by RT-qPCR ( $\mathrm{p}=0.015)$.

Figure 2. DNA methylation analysis of candidate FS-DMR in the FASSTT study.

SMART-MSP was used to examine DNA methylation at RASA4 (A), DHFR (B) and DHFR2 (C) and MS-HRM at RASSF1A (D), EIF2C3 (E) and ATPF1 (F). The number of $\mathrm{CpG}$ sites analysed is indicated by the lollipops including the region relative to the Transcription Start Site (TSS) for each gene. The percentage methylation difference was calculated in the pre- versus post-intervention sample for each individual for both arms of the trial (folic acid (FA) or placebo) and then grouped by individuals that showed no change in methylation $(-10 \%-+10 \%)$, increased methylation of more than $10 \%(>10 \%)$ or decreased methylation of greater than $10 \%(<10 \%)$. DHFR2, RASSF1A, EIF2C3 and ATPF1 showed no change in methylation in all individuals, while RASA4 and DHFR showed methylation changes in some individuals but there were no statistically significant differences between placebo and FA intervention groups (Single factor ANOVA analysis RASA4 $(\mathrm{p}=0.9) ; \operatorname{DHFR}(\mathrm{p}=0.404))$. 
Table 1. Samples selected from the FASSTT trial for the pilot genome-wide DNA methylation analysis

\begin{tabular}{|l|lll|llc|}
\hline Sample + & \multicolumn{3}{|c|}{ Pre-Intervention } & \multicolumn{3}{c|}{ Post-Intervention } \\
\hline & pl. folate $\neq$ & RCF $\$$ & Hcy $~$ & pl. folate & RCF & Hcy \\
& nmol/L & $n$ nol/L & $\mu$ mol/L & nmol/L & nmol/L & $\mu \mathrm{mol} / \mathrm{L}$ \\
FA 1 & 23.4 & 497 & 4.9 & 42.0 & 1123 & 5.2 \\
FA 2 & 43.5 & 240 & 10.4 & 60.2 & 1540 & 6.9 \\
FA 3 & 43.8 & 848 & 5.5 & 72.8 & 1191 & 5.4 \\
Placebo 1 & 18.2 & 378 & 14.2 & 5.6 & 425 & 14.0 \\
Placebo 2 & 50.0 & 942 & 5.7 & 15.2 & 623 & 6.7 \\
Placebo 3 & 42.9 & 750 & 4.5 & 13.4 & 802 & 4.9 \\
\hline
\end{tabular}

$t$ Samples with 'FA' in the identifier are those individuals in the folic acid arm of the intervention trial; samples with 'Placebo' in the identifier are those individuals in the placebo arm of the intervention trial.

$\mp$ pl. folate $=$ plasma folate

$\S \mathrm{RCF}=$ red cell folate

I Hcy = plasma homocysteine 